\title{
Terrestrial Photovoltaic Module Accelerated Test-to-Failure Protocol
}

C.R. Osterwald

Technical Report NREL/TP-520-42893

March 2008

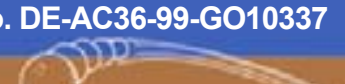




\title{
Terrestrial Photovoltaic Module Accelerated Test-to-Failure Protocol
}

\author{
C.R. Osterwald
}

Prepared under Task No. PVB7.6701

Technical Report NREL/TP-520-42893

March 2008

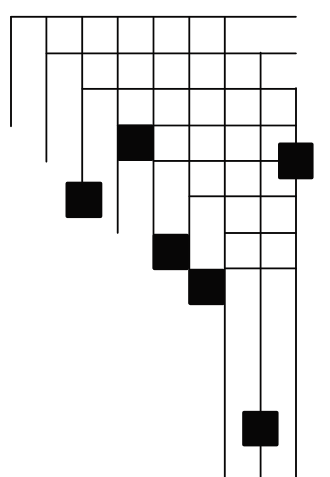

National Renewable Energy Laboratory 1617 Cole Boulevard, Golden, Colorado 80401-3393 303-275-3000 • www.nrel.gov 


\section{NOTICE}

This report was prepared as an account of work sponsored by an agency of the United States government. Neither the United States government nor any agency thereof, nor any of their employees, makes any warranty, express or implied, or assumes any legal liability or responsibility for the accuracy, completeness, or usefulness of any information, apparatus, product, or process disclosed, or represents that its use would not infringe privately owned rights. Reference herein to any specific commercial product, process, or service by trade name, trademark, manufacturer, or otherwise does not necessarily constitute or imply its endorsement, recommendation, or favoring by the United States government or any agency thereof. The views and opinions of authors expressed herein do not necessarily state or reflect those of the United States government or any agency thereof.

Available electronically at http://www.osti.gov/bridge

Available for a processing fee to U.S. Department of Energy and its contractors, in paper, from:

U.S. Department of Energy

Office of Scientific and Technical Information

P.O. Box 62

Oak Ridge, TN 37831-0062

phone: 865.576 .8401

fax: 865.576 .5728

email: mailto:reports@adonis.osti.gov

Available for sale to the public, in paper, from:

U.S. Department of Commerce

National Technical Information Service

5285 Port Royal Road

Springfield, VA 22161

phone: 800.553.6847

fax: 703.605.6900

email: orders@ntis.fedworld.gov

online ordering: http://www.ntis.gov/ordering.htm 


\section{Table of Contents}

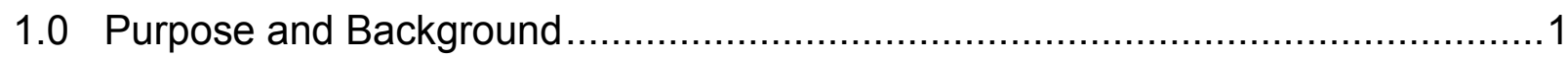

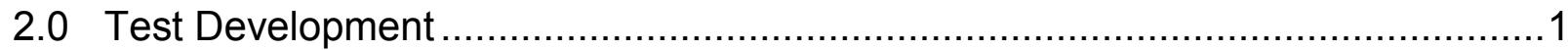

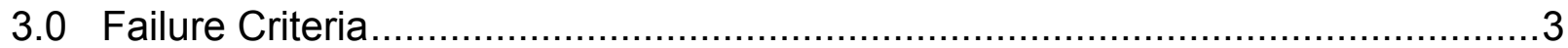

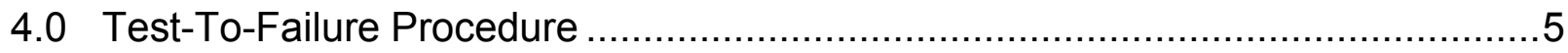

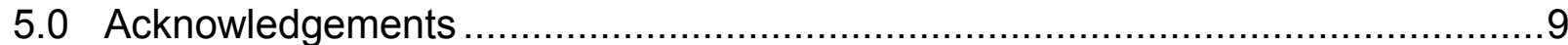

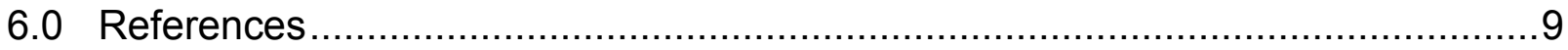




\subsection{Purpose and Background}

The purpose of this report is to document a test-to-failure (TTF) protocol that may be used to obtain quantitative information about the reliability of photovoltaic (PV) modules using accelerated testing in environmental temperature-humidity chambers. Reliability information is determined by subjecting test modules to temperature-humidity conditions that are known to stress common module failure mechanisms until the test modules no longer have acceptable performance. The duration of the applied stresses that the test subject survives provides an indication of its reliability and allows comparisons to other products.

Qualification tests for PV modules have been available as consensus standards for many years. Two of the stress tests, thermal cycling (TC) and damp heat exposure (DH), are selected as the stresses for this TTF protocol [1-3]. In the standard qualification sequences the duration of these tests are proscribed, 200 cycles and 1000 hours, and both require about six weeks to run.

It is important to note that the relatively short test sequences in the qualification standards do not and cannot provide lifetime data, even though they are designed to determine if common and known module failure modes are active. Reliability testing, on the other hand, involves determining when and how a test subject fails, as defined by Hoffman and Ross of the Jet Propulsion Laboratory (JPL) [4]:

"In contrast with qualification tests, reliability and life-prediction tests are designed to provide quantitative information on projected mean-time-between failures or lifetimes. Such analyses are generally site specific or mission specific and often lengthy for products requiring MTBF's or lifetimes of many years." (Emphasis in original.)

Accelerated lifetime tests that can be correlated with actual use conditions are difficult to perform on modules for a number of reasons, including the limited number of variables that can be accelerated (solar duty cycle, irradiance, temperature, humidity), as well as the physical sizes of modules.

The test protocol provided in this report can thus be seen as falling between qualification testing and true accelerated life testing. Qualification testing uses (mostly) artificial indoor tests to obtain quality information as quickly as possible, whereas life testing needs to replicate actual use conditions as closely as possible in order to obtain lifetime data. The TTF protocol extends the artificial indoor stresses from the proscribed lengths by continuing the environmental chamber testing until module failure is detected. These lengths are not module lifetimes, but they can be used to compare the reliability of different modules on a quantitative basis.

\subsection{Test Development}

Thermal cycling and damp heat were selected for the TTF protocol because these stresses have been reported by laboratories performing standard qualification tests to cause the highest numbers of failures [5-7]. Reliability testing programs that use extended duration stresses borrowed from the standard qualification sequences have been reported in the literature [8-11], and DH testing-to-failure as used at BP Solar has been described by Wohlgemuth [9]. Origin Solar Energy performed extended duration TC and DH, as long as 1400 cycles and 4500 hours, 
for reliability studies of Si "SLIVER" modules [10]; BP Solar has published similar studies of crystalline-Si (x-Si) modules [11].

A number of years ago, a proposal was made in PV standards development committees to modify the original TC test by forcing test modules into forward bias at currents equal to the one-sun maximum power currents while the module temperatures are above $20^{\circ} \mathrm{C}$, because this additional stress was found to replicate solder bond degradation observed outdoors in use [1214]. This degradation is characterized by slow increases of series resistance and thus losses of fill factor. The second edition of IEC 61215 adopted this change [1] but the soon-to-bepublished revision of IEC 61646 for thin-film modules does not have forward-current biasing [2]. Thin-film modules are treated differently for two reasons: 1) they generally do not have a large number of solder bonds, and 2) forward-current bias produces the equivalent of lightinduced degradation in a-Si modules. However, thin-film modules still have internal electrical connections that carry current while in operation. For a-Si modules, thermal annealing can be used to reverse light-induced degradation, so there are no compelling reasons not to include forward current bias in thin-film modules.

These effects can be seen in Fig. 1, which shows an initial drop in output power in an a-Si module subjected to 400 thermal cycles with current bias. After thermal annealing, much of the drop is recovered, although the module still has suffered a $4 \%$ power loss compared to the unbiased module. Therefore, forward-biased TC is also a requirement of this TTF protocol for thin-film modules.

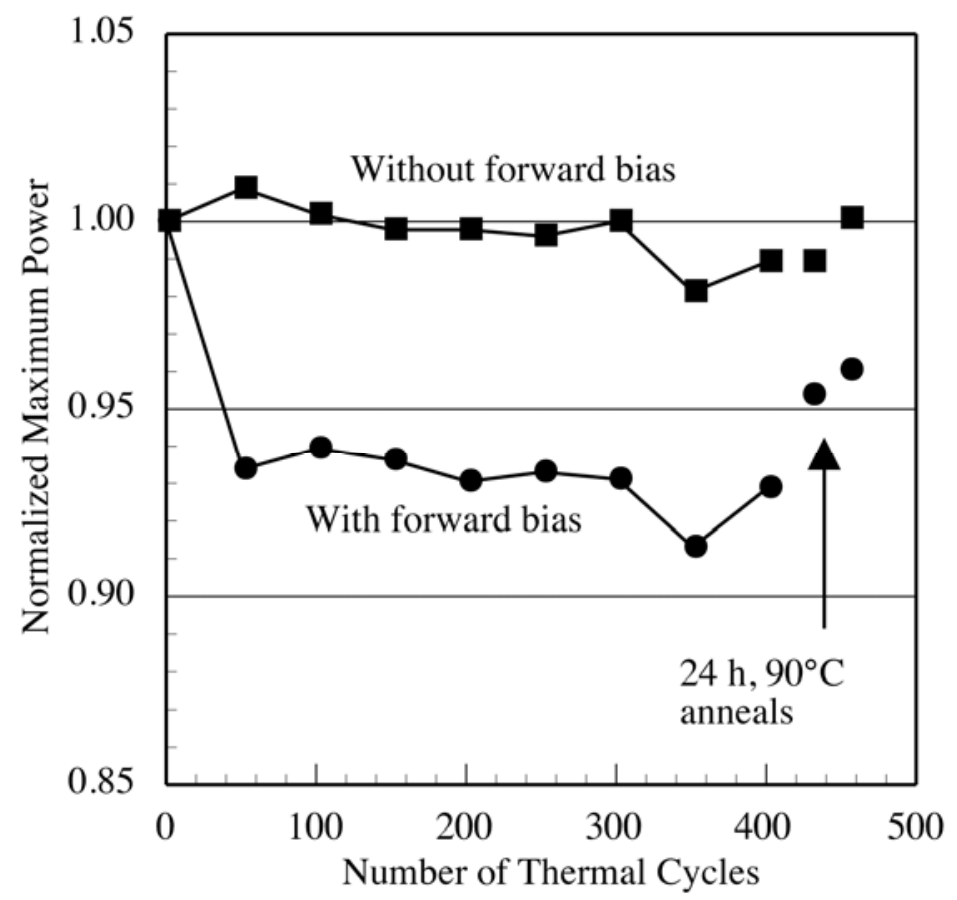

Figure 1. Normalized maximum output power versus number of thermal cycles for two Uni-Solar US-32 a-Si modules; data reported as Fig. 2 of Ref. [14]. At the conclusion of the thermal cycle testing, two $24-\mathrm{h}, 90^{\circ} \mathrm{C}$ annealing steps were performed. 
Voltage biasing during DH exposure (at $\pm 500 \mathrm{~V}$ ) was proposed by JPL in 1985 as a susceptibility test of metallic grids to electrochemical corrosion [15]. Later, BP Solar revived this proposal $[12,13]$, but the change was not adopted by the International Electrotechnical Commission (IEC) TC-82 standards committee for IEC 61215, as it was considered too strenuous. DH with voltage bias between the frame and the solar cells became a useful test of monolithic amorphous-Si (a-Si) modules for electrochemical corrosion and delamination of $\mathrm{SnO}_{2}: \mathrm{F}$ transparent-conducting thin films from glass superstrates [16, 17]. With consideration of this background, the TTF protocol therefore requires DH to be performed with voltage bias.

It has been noted that one stress can weaken the ability of a module to withstand a different stress, if it is applied sequentially [9, 18]. Quite a number of combined stresses can be imagined, and testing all such pairs is probably intractable. One pair was selected for the TTF protocol, so a combined DH-TC stress is included.

\subsection{Failure Criteria}

To test a sample until failure, criteria and metrics are needed to determine if a failure has occurred. For PV modules, such criteria are based on the electrical output power and the physical state of a module under test. The IEC qualification sequences have defined rigorous failure criteria that testing laboratories must use when determining if a particular module design has met the requirements for qualification (or "type approval") [1,2]. These requirements in the standard tests are used as a starting point for the TTF protocol and entail details such as:

- Maximum acceptable power losses

- No open circuits during testing

- Dry and wet insulation tests remain within proscribed limits

- No major visual defects, such as cracks, bubbles, delamination, distortion.

For $\mathrm{x}-\mathrm{Si}$ modules, power losses are determined with current-voltage (I-V) measurements before and after stress testing; IEC 61215 requires losses to be no larger than $8 \%$ of the initial values.

IEC 61646, on the other hand, has very different power loss requirements. This standard is intended for so-called thin-film modules, which include a-Si, CdTe/CdS, and $\mathrm{Cu}(\mathrm{In}, \mathrm{Ga}) \mathrm{S}_{2}$ (CIGS) modules (note that the standard does not include a formal definition of the term).

Because of inherent instabilities in these technologies (the natures of which vary among the three), IEC 61646 instead requires module power output to be within $90 \%$ of a minimum value specified by the manufacturer. Determination of the final power levels is made following a lightsoaking step that continues until output power is stabilized.

The $8 \%$ degradation limit for $\mathrm{x}-\mathrm{Si}$ modules in IEC 61215 is not intended to be a definition of the module lifetime, because it is generally recognized that modules will still be useful at this value in most applications. The same is true of the power limit in IEC 61646. Manufacturers typically offer warrantees on module power on the basis of $1 \%$ per year degradation, for periods of 10 to 20 years, and a 20 -year warrantee means that the manufacturer will replace a module whose output drops below $80 \%$ of the initial power. The $8 \%$ or $10 \%$ limits used with the qualification tests reflect the general opinion that the stresses imposed are representative of 5 to 10 years of 
use in a moderate climate and are therefore not definitions of module end-of-life. In any event, the ultimate end-of-life of a module remains application- and user-specific [19].

BP Solar has published data for power loss versus DH exposure time on x-Si modules [9]; these data are reproduced in Fig. 2 and show a precipitous increase in power loss after 2500 hours of exposure. This non-linear behavior is in contrast to thermal cycling degradation, which has been reported to be gradual and much more linear $[9,10,12,13]$. Catastrophic failures can occur during biased thermal cycling, however, such as an open interconnection or internal arcing developing during a test.

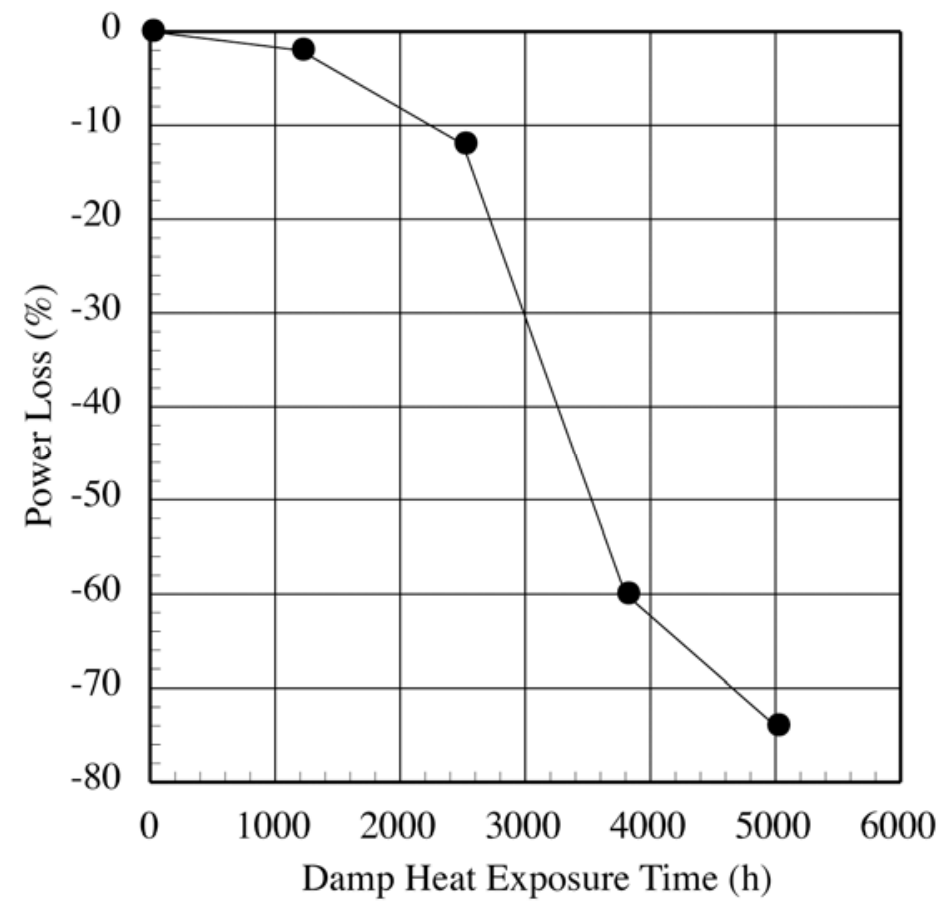

Figure 2. Power loss versus DH exposure time for a polycrystalline-Si module with screen-printed contacts; data reported by BP Solar in Fig. 4 of Ref. [9].

Whatever value of degradation limit that is selected for an accelerated module life test will have to be an arbitrary decision to a certain degree. Aside from a catastrophic failure occurring, the number of thermal cycles that a module can survive is a function of the limit selected; but this variability does not hinder the utility of the TTF, because the limit is applied uniformly to all modules. The results can still be used for numeric comparisons between different module types.

Using these considerations, the criteria used to determine when a module under test is deemed to have failed are:

- Loss of $50 \%$ of initial power output (x-Si)

- Power output less than $50 \%$ of the manufacturer's rating (a-Si, CdTe, CIGS)

- Arcing in module circuitry or junction box

- Failure of dielectric withstand or wet insulation resistance tests at end of test segment

- Leakage current greater than $50 \mu \mathrm{A}$ during biased DH exposure 
- Open-circuit fault during forward-biased TC

- Development of major visual defects.

\subsection{Test-to-Failure Protocol}

As seen in Fig. 3, the TTF protocol is organized into three repeating loops, one for each of the three stresses. The loops allow the ongoing testing to be interrupted for the recharacterization that is needed to determine if a failure has occurred during the latest test segment, or to allow for insertion of new modules. Recovery treatments are performed on thin-film modules following the recharacterizations to minimize false failures caused by instabilities unrelated to the stress testing.

Although the protocol is intended to stress modules until failure occurs, the number of repetitions is limited to 15 in the event that a module design is able to survive such extreme amounts of stress. This limitation places an upper bound on the amount of testing a laboratory is required to perform on a single module design (3000 thermal cycles and $15000 \mathrm{~h}$ of DH). In such cases, the amount of total power loss is reported instead of the number of thermal cycles and hours of damp heat until failure.

Upon receipt of a group of modules to be subjected to the TTF protocol, the procedure is to record the manufacturer's maximum system voltage $\left(V_{s y s}\right)$ rating and minimum maximum power $\left(P_{\min }\right)$ at standard reporting conditions (SRC) rating. Then randomly assign the seven modules to the control, DH, TC, and combined DH-TC sequences, A through D in Fig. 3.

To minimize the testing resources needed, split the two Seq. D modules and subject one module to DH exposure with the Seq. B modules while the other is subjected to TC with the Seq. C modules. At the beginning of each successive stress segment, swap the Seq. D modules to effect the combined TC-DH stress required for Seq. D.

\subsection{Light Soak}

Subject crystalline-Si modules only to a light-soaking step to stabilize the short-circuit currents $\left(I_{s c}\right)$ according to Sec. 5 of IEC 61215 (such light-induced degradation is typically caused by a B$\mathrm{O}$ instability phenomenon). The $5 \mathrm{kWh} / \mathrm{m}^{2}$ total dose is approximately equivalent to a single sunny day at latitude tilt in January in Golden, Colorado.

\subsection{Characterization}

Module characterization consists of several tests: a maximum power-point $\left(P_{\max }\right)$ measurement, a dielectric withstand test, a wet insulation resistance measurement, a visual inspection, and optional infrared imaging. These may be performed in any convenient order, but note that the insulation tests must be performed within 2-4 h after completion of a DH exposure. 
START

7 modules

\section{Light Soak ( $x$-Si only) \\ (4.1)}

$\downarrow$

Characterization

(4.2)

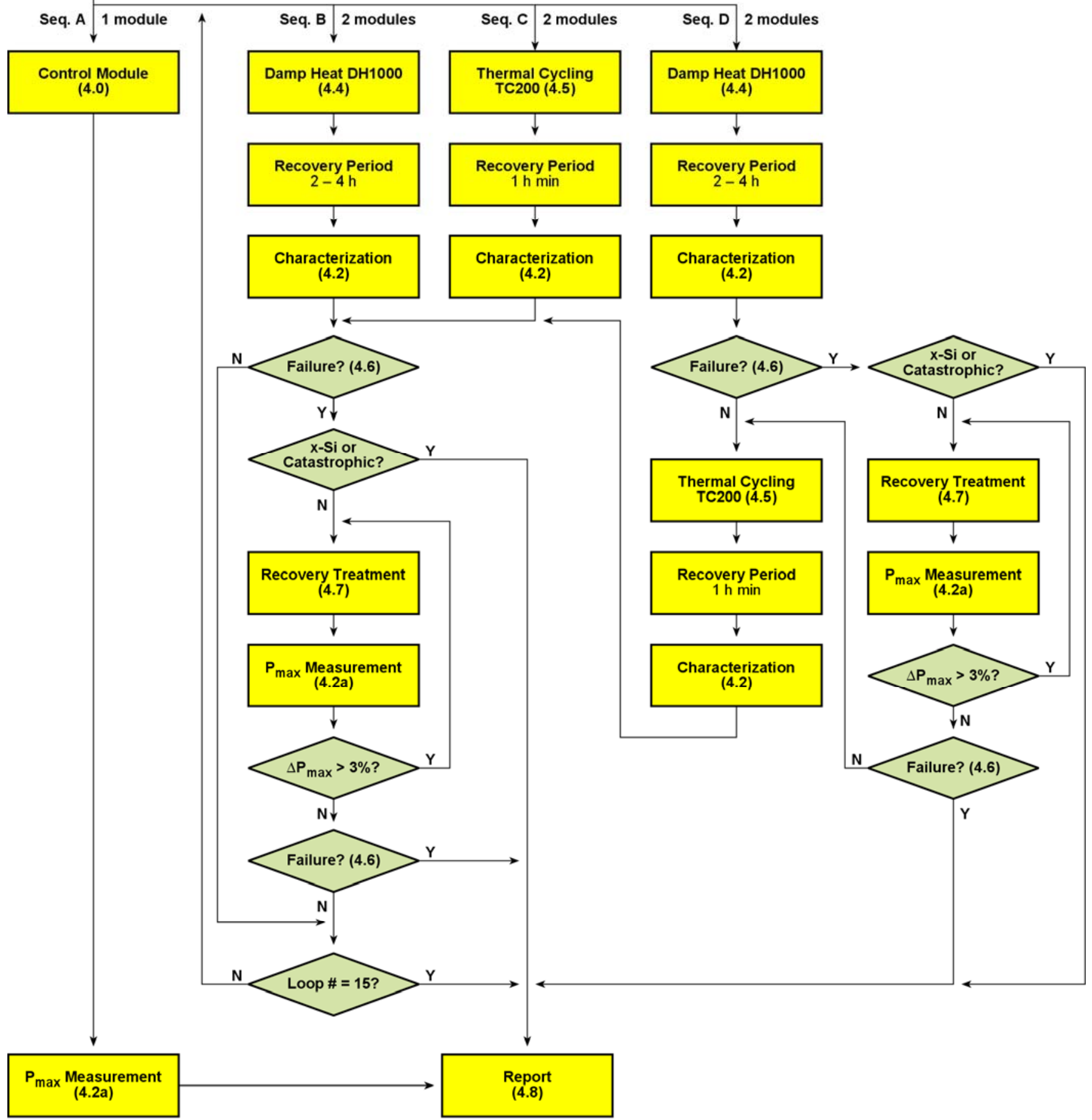

END

Figure 3. Flow sequence of the module test-to-failure protocol. 
a) $P_{\max }$ Measurement - Measure the module maximum power point at any convenient set of reporting conditions (see 3.2.2 of ASTM E 1036 [20]). Because module failure is defined in terms of relative changes, repeatability of the $P_{\max }$ measurement is the most important requirement, rather than the absolute power at any given irradiance. Adhere to the requirements of Sec. 10.2 of IEC 61215 or IEC 61646, as appropriate. Series-connected multijunction modules should be measured according to ASTM E 2236 [21]. If possible, measure the currentvoltage curve beyond the open-circuit voltage $\left(V_{o c}\right)$ so that a series resistance calculation can be performed.

b) Dielectric Withstand - Perform a dielectric withstand test of the modules' insulation according to Sec. 7.1 of ASTM E 1462 [22]. It is not necessary to perform the opposite polarity test specified in Sec. 7.1.12.

c) Wet Insulation Resistance - Measure the modules' insulation resistance while submerged using Sec. 7.3 of ASTM E 1802 [23].

d) Visual Inspection - Document the modules' physical appearance with a visual inspection as defined in Sec. 10.1 of both IEC 61215 and IEC 61646, as appropriate, and determine if any major visual defects are present using the definitions in Sec. 7 of both IEC 61215 and IEC 61646, as appropriate. Additional information and details about performing visual inspections is contained in ASTM E 1799 [24].

e) Infrared Imaging - As an option, obtain infrared images of the modules while operating in forward bias or reverse bias, or both. Available techniques include thermal images at wavelengths greater than about $2 \mu \mathrm{m}$ [13], or forward-bias electroluminescence images at wavelengths corresponding to semiconductor bandgaps (about $1.1 \mu \mathrm{m}$ for $\mathrm{Si}$ ) [25]. Infrared images are not used to determine failure, but are useful for determining and locating failures.

\subsection{Control Module}

Retain the module designated as the control for Seq. A in a safe location away from sunlight. Perform a $P_{\max }$ measurement on this module each time intermediate characterizations are made on the modules subjected to the stress sequences. Note that CdTe modules can lose $V_{o c}$ while in dark storage; these losses are normally reversible with light soaking.

\subsection{Damp Heat DH1000}

Subject test modules to $1000 \mathrm{~h}$ of $85^{\circ} \mathrm{C} / 85 \% \mathrm{RH}$ according to the procedure specified by Sec. 6.7 of ASTM E 1171. During DH exposure, for all Seq. B and Seq. D modules, provide a voltage bias equal to $V_{\text {sys }}$ between the modules' designated grounding points (located on the frames of modules with metallic frames) and the shorted output leads, at both polarities. Record the leakage current through the module leads to the grounding point. If the test module lacks a designated grounding point, the test cannot be performed with voltage bias. Ref. [17] contains additional information about $\mathrm{DH}$ testing with voltage bias. 


\subsection{Thermal Cycling TC200}

Subject test modules to 200 thermal cycles according to Sec. 10.11 of IEC 61215. Additional information about forward-biased thermal cycling is contained in Sec. 6.5 of ASTM E 1171. During the TC200 test, record the current through the modules so that the cycle number during which any open-circuit faults occur can be determined. If an open-circuit fault occurs, the test modules may be removed from the test chamber at any convenient time.

\subsection{Failure Determination}

Determine if any modules have failed using the following criteria:

- Power output less than $50 \%$ of the initial $P_{\max }(\mathrm{x}-\mathrm{Si})$

- Power output less than $50 \%$ of the manufacturer's $P_{\min }$ rating following a recovery treatment (a-Si, CdTe, CIGS)

- Arcing in module circuitry or junction box

- Failure of dielectric withstand test as defined in Sec. 10.3.5 of IEC 61215

- Failure of wet insulation resistance test as defined in Sec. 10.15.4 of IEC 61215

- Leakage current greater than $50 \mu \mathrm{A}$ during biased DH exposure

- Open-circuit fault during forward biased TC

- Development of major visual defects:

- $\quad$ As defined in IEC 61215 sections 7a, 7b, 7d, and 7e

- Corrosion of any active part of the electrical circuit greater than $50 \%$ in area of any cell.

Failure of either module of a pair subjected to one of the three stress legs in Fig. 3 shall constitute failure of both modules. A catastrophic failure is defined as any failure other than the power loss criteria, or the output power falling to less than $20 \%$ of the initial value, or the manufacturer's $P_{\min }$ rating, as appropriate.

\subsection{Recovery Treatment}

$x-S i$ - Not applicable.

$a-S i$ - Subject a-Si modules to a thermal anneal of $90^{\circ} \mathrm{C} \pm 2^{\circ} \mathrm{C}$ for $24 \mathrm{~h}$. This procedure was adapted from Sec. 5.19 of IEEE 1262 [26].

CdTe, CIGS - Subject CdTe and CIGS modules to an outdoor light soak with resistive loads for a total dose of $50 \mathrm{kWh} / \mathrm{m}^{2}$. This dose is approximately two weeks in Golden, Colorado. Additional information about light soaking thin-film modules is available in Sec. 10.19 of IEC 61646. 


\subsection{Report}

At the conclusion of the test-to-failure sequence, prepare a report that documents the results of the $\mathrm{DH}$ and $\mathrm{TC}$ testing. Include the following:

- Module description, including manufacturer, model numbers, serial numbers, grounding point, and sequence allocations

- Number of hours of damp heat exposure with voltage biasing in Seq. B required to induce failure, or the power losses at the end of $15000 \mathrm{~h}$

- Description of failure during DH stress

- Number of thermal cycles with forward current biasing Seq. C required to induce failure, or the power losses at the end of 3000 cycles

- Description of failure during TC stress

- Number of combined DH-TC Seq. D segments survived without failure

- Description of failure during combined DH-TC stress

- Graphical plots of power loss versus time or number of cycles, such as Fig. 1

- Graphical plots of module series resistance versus time or number of cycles, if available

- Description of $P_{\max }$ measurement procedure used

- Tabular summary of each $P_{\max }$ measurement, including $I_{s c}, V_{o c}, I_{\max }, V_{\max }$, and $R_{\text {series }}$

- Visual inspection results, including any photographic images

- Any infrared images helpful for failure documentation

- Tabular summary of dielectric withstand and wet insulation resistance tests.

\subsection{Acknowledgements}

Discussions with Tom McMahon, John Wohlgemuth, Kent Whitfield, and Liang Ji provided a great deal of insight during the development of this protocol, and their contributions are gratefully acknowledged. This work is supported or funded under U.S. Department of Energy Contract No. DE-AC36-99GO10337.

\subsection{References}

[1] International Electrotechnical Commission. "Crystalline silicon terrestrial photovoltaic (PV) modules - design qualification and type approval." CEI/IEC 61215:2005, Geneva, Switzerland, 2005.

[2] International Electrotechnical Commission. "Thin film terrestrial photovoltaic (PV) modules - design qualification and type approval." IEC 61646 ed. 2, Final Draft International Standard, Geneva, Switzerland, 2007.

[3] ASTM International, Annual Book of Standards, vol. 12.02. "Standard test method for photovoltaic modules in cyclic temperature and humidity environments." ASTM International Standard E 1171, Philadelphia, PA, USA, 2007.

[4] A.R. Hoffman, R.G. Ross. "Environmental qualification testing of terrestrial solar cell modules". Proceedings of the 13th IEEE PV Specialists Conference, Washington, DC, USA, 1978; 835. 
[5] J. Bishop, H. Ossenbrink. "Results of five years of module qualification testing to CEC Specification 503". Proceedings of the 25th IEEE PV Specialists Conference, Washington, DC, USA, 1996; 1191.

[6] T. Sample, A. Skoczek, E.D. Dunlop, H.A. Ossenbrink. "Data analysis of electrical performance measurements from 15 years of module qualification tests". Proceedings of the 4th World Conference on PV Energy Conversion, Waikoloa, Hawaii, USA, 2006; 2042.

[7] B. Li, T. Arends, J. Kuitche, W. Shisler, Y. Kang, G. TamizhMani. "IEC and IEEE design qualifications: an analysis of test results acquired over nine years". Proceedings of the 21st European Photovoltaic Solar Energy Conference, Dresden, Germany, 2006; 2078.

[8] J.I. Hanoka. "Accelerated testing of an encapsulant for PV modules". Proceedings of the 29th IEEE PV Specialists Conference, New Orleans, Louisiana, USA, 2002; 1565.

[9] J.H. Wohlgemuth, D.W. Cunningham, A.M. Nguyen, J. Miller. "Long term reliability of PV modules". Proceedings of the 20th European Photovoltaic Solar Energy Conference, Barcelona, Spain, 2005; 1942.

[10] M.J. Stocks, D. Gordeev, M.J. Kerr, G.J. Lavery, N. Tothill, P. Mackey, P.J. Verlinden. "The technical and performance advantages of production SLIVER modules". Proceedings of the 4th World Conference on PV Energy Conversion, Waikoloa, Hawaii, USA, 2006; 2081.

[11] J.H. Wohlgemuth, D.W. Cunningham, P. Monus, J. Miller, A. Nguyen. "Long term reliability of photovoltaic modules". Proceedings of the 4th World Conference on PV Energy Conversion, Waikoloa, Hawaii, USA, 2006; 2050.

[12] J. Wohlgemuth. "Reliability testing of PV modules at Solarex". Proceedings of the 1998 Photovoltaic Performance and Reliability Workshop, NREL/BK-520-25850, Cocoa Beach, Florida, USA, 1998.

[13] J.H. Wohlgemuth, M. Conway, D.H. Meakin. "Reliability and performance testing of photovoltaic modules". Proceedings of the 28th IEEE PV Specialists Conference, Anchorage, Alaska, USA, 2000; 1483.

[14] C.R. Osterwald, J. Pruett, S. Rummel, A. Anderberg, L. Ottoson. "Forward-biased thermal cycling: a new module qualification test". Proceedings of the $2000 \mathrm{NCPV}$ Program Review Meeting, NREL BK-520-28064, Denver, Colorado, USA, 2000.

[15] M.I. Smokler, D.H. Otth, R.G. Ross. "The Block program approach to photovoltaic module development". Proceedings of the 18th IEEE PV Specialists Conference, Las Vegas, Nevada, USA, 1985; 1150.

[16] D.E. Carlson, R. Romero, F. Willing, D.H. Meakin, L. Gonzalez, R. Murphy, "Corrosion effects in thin-film photovoltaic modules." Progress in Photovoltaics: Research Applications 2003; 11: 377, DOI: 10.1002/pip.500.

[17] C.R. Osterwald, T.J. McMahon, J.A. del Cueto, "Electrochemical corrosion of $\mathrm{SnO}_{2}: \mathrm{F}$ transparent conducting layers in thin-film photovoltaic modules." Solar Energy Materials \& Solar Cells 2003; 79: 21.

[18] J. Wohlgemuth, personal communication, 2008.

[19] A. Schlumberger. "Right down to the last electron," in PHOTON International, Aug. 2006; 74.

[20] ASTM International, Annual Book of Standards, vol. 12.02. "Standard test methods for electrical performance of nonconcentrator terrestrial photovoltaic modules and arrays using reference cells." ASTM International Standard E 1036, Philadelphia, PA, USA, 2007. 
[21] ASTM International, Annual Book of Standards, vol. 12.02. "Standard test methods for measurement of electrical performance and spectral response of nonconcentrator multijunction photovoltaic cells and modules." ASTM International Standard E 2236, Philadelphia, PA, USA, 2007.

[22] ASTM International, Annual Book of Standards, vol. 12.02. "Standard test methods for insulation integrity and ground path continuity of photovoltaic modules." ASTM

International Standard E 1462, Philadelphia, PA, USA, 2007.

[23] ASTM International, Annual Book of Standards, vol. 12.02. "Standard test methods for wet insulation integrity testing of photovoltaic modules." ASTM International Standard E 1802, Philadelphia, PA, USA, 2007.

[24] ASTM International, Annual Book of Standards, vol. 12.02. "Standard practice for visual inspections of photovoltaic modules." ASTM International Standard E 1799, Philadelphia, PA, USA, 2007.

[25] A.M. Gabor, M. Ralli, S. Montminy, L. Alegria, C. Bordonaro, J. Woods, L. Felton, M. Davis, B. Atchley, T. Williams. "Soldering induced damage to thin Si solar cells and detection of cracked cells in modules". Proceedings of the 21st European Photovoltaic Solar Energy Conference, Dresden, Germany, 2006; 2042.

[26] Institute for Electrical and Electronic Engineers. "IEEE recommended practice for qualification of photovoltaic (PV) modules." IEEE Standard 1262-1995, New York, New York, 1996. 


\section{REPORT DOCUMENTATION PAGE}

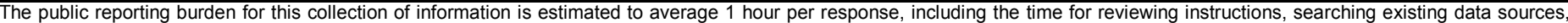

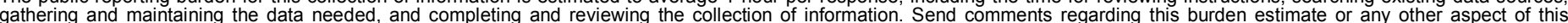

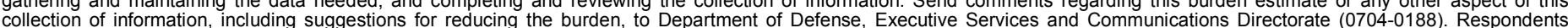

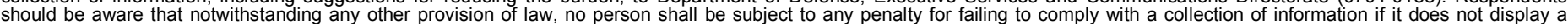

should be aware that notwithstar

PLEASE DO NOT RETURN YOUR FORM TO THE ABOVE ORGANIZATION.

\begin{tabular}{l|l|l|l} 
1. REPORT DATE $(D D-M M-Y Y Y Y)$ & 2. REPORT TYPE & 3. DATES COVERED (FrOm - TO)
\end{tabular}

March 2008

Technical Report

4. TITLE AND SUBTITLE

Terrestrial Photovoltaic Module Accelerated Test-to-Failure Protocol

5a. CONTRACT NUMBER

DE-AC36-99-GO10337

5b. GRANT NUMBER

5c. PROGRAM ELEMENT NUMBER

6. AUTHOR(S)

C.R. Osterwald

5d. PROJECT NUMBER

NREL/TP-520-42893

5e. TASK NUMBER

PVB7.6701

5f. WORK UNIT NUMBER
7. PERFORMING ORGANIZATION NAME(S) AND ADDRESS(ES)

National Renewable Energy Laboratory

1617 Cole Blvd.

Golden, CO 80401-3393
8. PERFORMING ORGANIZATION REPORT NUMBER

NREL/TP-520-42893

9. SPONSORING/MONITORING AGENCY NAME(S) AND ADDRESS(ES)

10. SPONSOR/MONITOR'S ACRONYM(S) NREL

11. SPONSORING/MONITORING AGENCY REPORT NUMBER

12. DISTRIBUTION AVAILABILITY STATEMENT

National Technical Information Service

U.S. Department of Commerce

5285 Port Royal Road

Springfield, VA 22161

\section{SUPPLEMENTARY NOTES}

14. ABSTRACT (Maximum 200 Words)

This technical report documents a test-to-failure protocol that may be used to obtain quantitative information about the reliability of photovoltaic modules using accelerated testing in environmental temperature-humidity chambers.

Three stresses have been selected for the test-to-failure protocol; these are: 1) thermal cycling, 2) damp-heat exposure, and 3) combined thermal cycling and damp heat stress. Results of the testing cannot be used to assign a lifetime as a number of years to a module, but allow quantitative comparisons of different module designs.

15. SUBJECT TERMS

Photovoltaic; module; testing; accelerated; temperature; humidity

\begin{tabular}{|c|c|c|}
\hline 6. SECURIT & CLASSIFICATI & N OF: \\
\hline $\begin{array}{l}\text { a. REPORT } \\
\text { Unclassified }\end{array}$ & $\begin{array}{l}\text { b. ABSTRACT } \\
\text { Unclassified }\end{array}$ & $\begin{array}{l}\text { c. THIS PAGE } \\
\text { Unclassified }\end{array}$ \\
\hline
\end{tabular}

\begin{tabular}{l|l|} 
17. & LIMITATION \\
OF ABSTRACT & $\begin{array}{l}\text { 18. } \\
\text { NUMBER } \\
\text { OF PAGES }\end{array}$ \\
UL & \\
&
\end{tabular}

19a. NAME OF RESPONSIBLE PERSON

19b. TELEPHONE NUMBER (Include area code) 